8. Originator Remarks:

Release of 209E Building Response to Ventilation Failure Evaluation

11. Receiver Remarks:

\begin{tabular}{|c|c|}
\hline $\begin{array}{l}\text { 2. To: (Receiving Organization) } \\
\text { Distribution }\end{array}$ & $\begin{array}{l}\text { 3. From: (originating Organization) } \\
\text { TWRS Radiological Control }\end{array}$ \\
\hline $\begin{array}{l}\text { 5. Proj./Prog./Dept./Div.: } \\
\text { 209E Building }\end{array}$ & $\begin{array}{l}\text { 6. Design Authority/ Design Agent/Cog } \\
\text { Engr.: } \\
\text { DJ Foust }\end{array}$ \\
\hline
\end{tabular}

11A. Design Basel ine Document?
[] Yes
[X] No

4. Related EDT No.: $N / A$

7. Purchase Order No.: $N / A$

9. Equip./Component Ho.: N/A

10. System/Bldg./Facility: 209E Building

12. Major Assm. Dwg. No.: N/A

13. Permit/Permit Application No.: $N / A$

14. Required Response Date: $7 / 23 / 98$

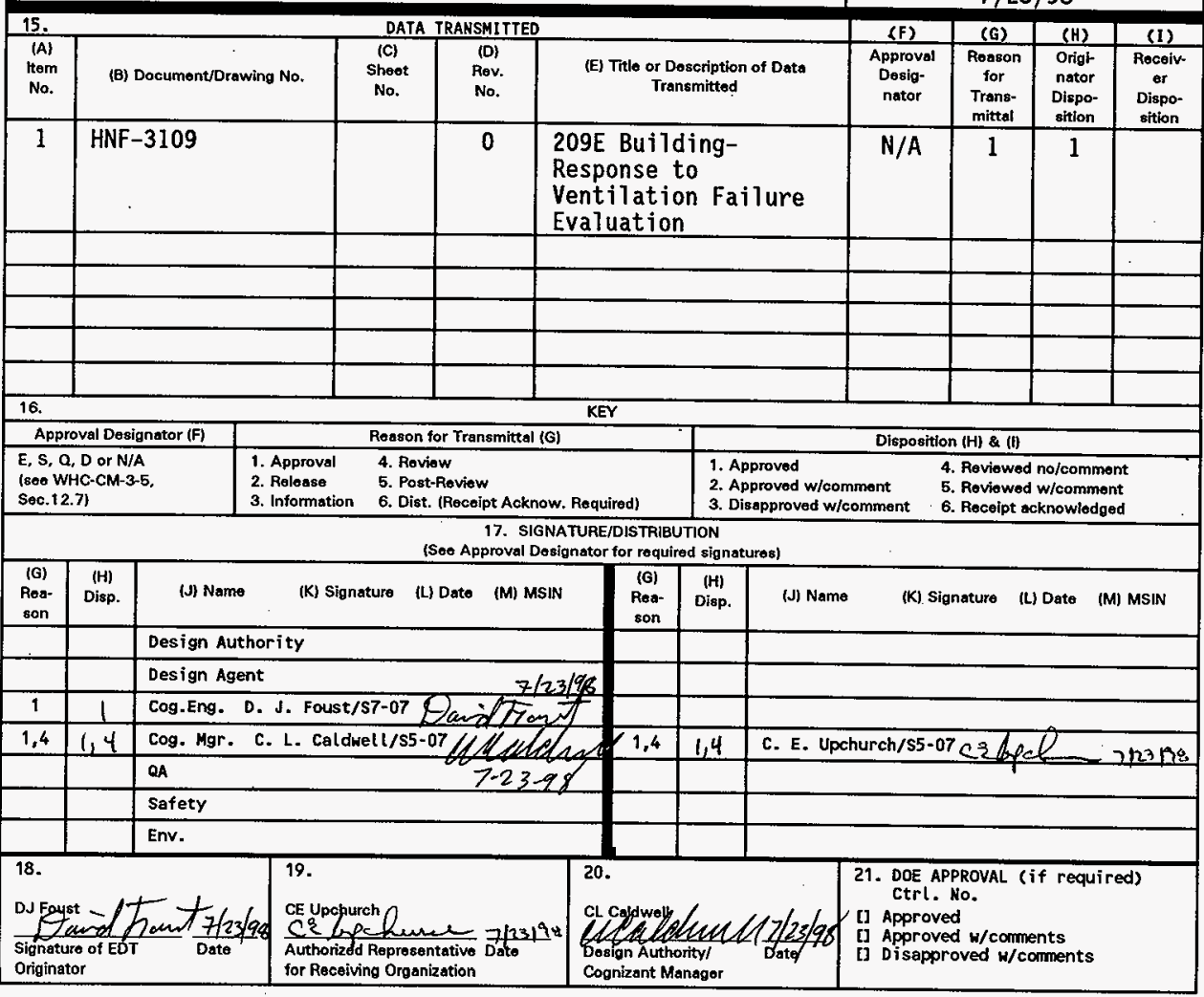

BD-7400-172-2 (05/96) GEF097 
HNF-3109

Rev. 0

\title{
209-E Building - Response to Ventilation Failure Evaluation
}

\author{
D. J. Foust
}

Lockheed Martin Hanford Corporation

Richland, WA 99352

U. S. Department of Energy Contract DE-AC06-96RL13200

\author{
EDT/ECN: EDT-622072 \\ UC: 607 \\ Org Code: LJG20000 \\ Charge Code: NF24D \\ B\&R Code: NA \\ Total Pages: $\$ 8$

$$
68 \text { \%ins } \% / 27 / 98
$$

Key Words: Air Monitoring, Real-time Air Monitoring, Continuous Air Monitor, CAM, Work Place Air Sampling

Abstract: This document provides an evaluation and recommendations for radiological workplace air monitoring and response to ventilation failure for the Critical Mass Laboratory, 209E Building.

TRADEMARK DISCLAIMER. Reference herein to any specific commercial product, process, or service by trade name trademark, manufacturer, or otherwise, does not necessarily constitute or impiy its endorsement, recommendation, or favoring by the United States Government or any agency thereof or its contractors or subcontractors.

Printed in the United States of America. To obtain copies of this document, contact: Document Control Services, P.O. Box 950, Mailstop H6-08, Richland WA 99352, Phone (509) 372-2420; Fax (509) 376-4989.
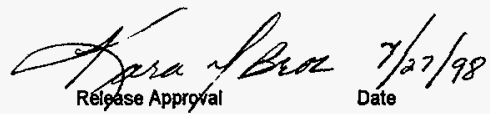

Approved for Public Release

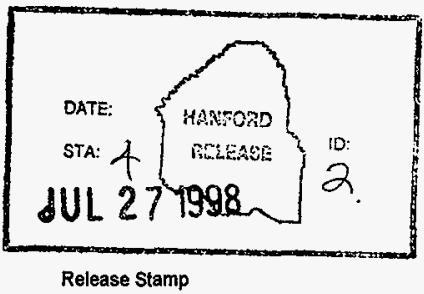

Release Stamp 
HNF-3109

Rev 0

Page 1 of 7

\title{
209E Building \\ Response to \\ Ventilation Failure \\ Evaluation
}

\author{
July 1998 \\ D. J. Foust
}

TWRS Radiological

Control Engineering

And Technical Support 


\section{Introduction}

The Critical Mass Laboratory, part of the 209E Building, is located in the 200-East Area of the Hanford Site. The facility was designed to provide a heavily shielded reactor room where plutonium and uranium liquid solutions could be brought into various critical configurations under carefully controlled and monitored conditions. The facility is contained with in a one-story L-shaped concrete block and reinforced concrete building. One wing houses offices, a control room, shops, and a common area while the other wing includes an equipment room, the change room, work areas, and the two-story Critical Assembly Room (CAR). Three of the rooms contain radiologically contaminated equipment and material; the CAR, the Mix Room, and the "hot side" of the change room. Figure 1 is a detailed plan view of $209 \mathrm{E}$.

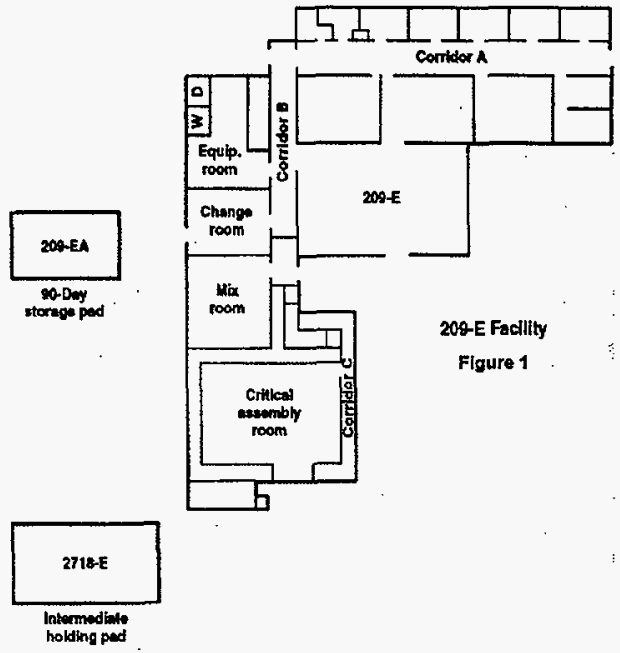

The CAR is where criticality experiments were conducted. Its three outside walls are five feet thick, the inside wall is three feet thick and the floor and ceiling are two feet thick. Previously this room had its own filtered ventilation supply, but that system is now isolated and the inlet damper is blocked in the closed position. Therefore, air is supplied by infiltration only. Currently, the CAR environment is monitored by a continuous air monitor (CAM) only during entries. The exhaust system consists of a control valve, fire resistant HEPA filters, an exhaust fan and a stack outside the building. The exhaust damper is secured in the open position to provide a flow path out of the facility even if the fan is not running. The CAR contains many pieces of contaminated equipment including four hoods or glove boxes, twelve tanks, and miscellaneous vessels and bottles. One additional tank is located adjacent to the south end of the CAR. Figure 2 is a detailed plan view of the CAR. 


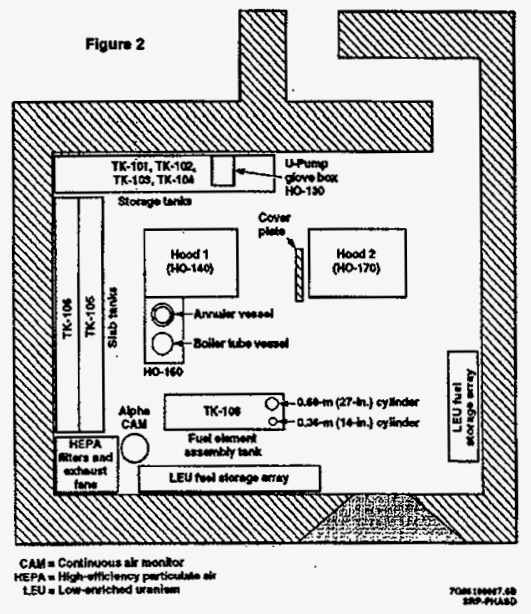

The Mix Room provided facilities for receiving and handling the plutonium and uranium, and for preparation of the various solutions of plutonium used in the experiments. This room is served by the main building exhaust system. This room also contains many pieces of contaminated equipment including three hoods or glove boxes, and nine tanks. The most prominent feature in the Mix Room is the mixing hood which provided containment for operations involving plutonium. Figure 3 is a detailed plan view of the Mix Room.

Flaures

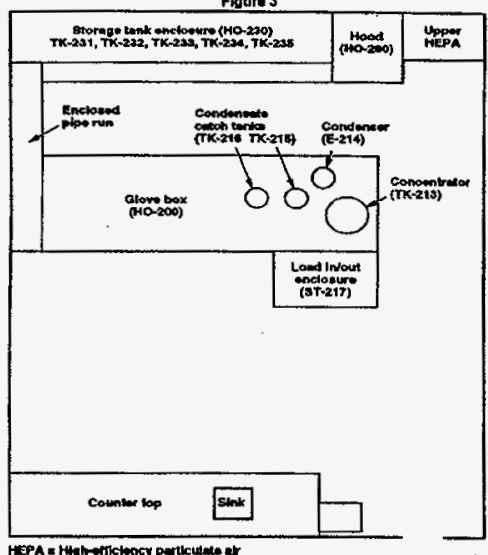


The contamination in the facility is contained in the CAR and the Mix Room. Both the CAR and the Mix Room contain plutonium as surface contamination on the inside of many pieces of equipment such as hoods, gloveboxes, tanks, and miscellaneous vessels and bottles. In addition, the floor of the CAR has some residual contamination fixed under paint.

The facility no longer has a mission, other than utilization of existing office space, and is awaiting final closure and decontamination and decommissioning.

\section{Scope}

The scope of this document is limited to an evaluation of air sampling requirements and response in the occupied portions of $209 \mathrm{E}$ in the event of an ventilation failure.

\section{Workplace Air Monitoring Requirements}

Workplace air monitoring is performed based upon actual or potential radiological conditions. The occupied portion of $209 \mathrm{E}$ is free of radioactive contamination, thus there is no actual airborne radioactivity. The determination of the necessity for workplace air monitoring in the occupied portion of $209 E$ is based on the potential for release of radioactive material from the CAR and Mix Room.

The residual plutonium remaining in the CAR and Mix Room is mainly in the form of surface contamination inside tanks and other vessels. The material is assumed to be ${ }^{239} \mathrm{Pu}$ in a soluble chemical form (worst case). There is assumed to be $230 \mathrm{~g}{ }^{239} \mathrm{Pu}(14.1$ $\mathrm{Ci})$ in the CAR and $185 \mathrm{~g}^{239} \mathrm{Pu}(11.3 \mathrm{Ci})$ in the Mix Room (WHC 1996).

Contamination remains in the Mix Room Glove Box HO-200; plutonium pump glove box HO-120; plutonium storage slab tanks TK-103,104, 105, 106, 231, 232, 233, 234, and 235; and remaining experimental vessels. The experimental vessels include a slab tank in $\mathrm{HO}-140$, an annular tank, and a tank with re-entrant tubes in HO-160, cylinder in TK108 , inserts for the annular tank stored in HO-170, an annular tank (containing $93 \%$ of plutonium stored in the CAR), a condensate storage tank TK-101, a waste holdup tank TK-111, a dump tank TK-109, and process lines connecting these vessels. This contamination is not accessible without breaking the barriers that isolate these items from contact.

Floor areas have embedded contamination that was cleaned without removing concrete, and then painted yellow to show that contamination is present.

These tanks and vessels represent the primary barrier to the release of radioactive material to occupied portions of the 209E Building. The CAR and Mix Room are surveyed on a quarterly basis to verify the integrity of this containment. These surveys are required by HSRCM-1.

All entrances to the CAR and Mix Room are currently locked and access is controlled. The physical walls and doors of these rooms make up the secondary barrier to the release of radioactive material to the occupied portions of $209 E$. Surveys are performed 
weekly to verify the integrity of this containment. These surveys are required by HSRCM-1.

The third barrier to release of radioactive material to occupied portions of the facility is the building ventilation system. Air is moved from the occupied portions of the facility toward the contaminated areas, and exhausted through a HEPA filtered exhaust. The operation of the ventilation system is required to be verified quarterly. This surveillance is required per the 209E Authorization Basis.

\section{Real-time Air Monitoring}

The requirement for real-time air monitoring in 10 CFR 835 is stated as follows:

835.403(a)(2) Real-time air monitoring, using continuous air monitors as defined in Sec. 835.2, shall be performed in normally occupied areas where an individual is likely to be exposed to a concentration of airborne radioactivity exceeding 1 DAC as specified in appendix $A$ of this part or where there is a need to alert potentially exposed individuals to unexpected increases in airbome radioactivity.

The potential for 1 DAC airbome radioactivity concentration in the occupied portions of the facility arise from the Pu contamination in the CAR and Mix rooms, but the three barriers described above, make exposure to such concentration is not likely. No single failure of any barrier would result in airborne concentrations exceeding 1 DAC in occupied areas.

Implementation Guidance provided in section IV of DOE G 441.8-1 specifies that readtime air monitoring shall be performed where unexpected increases in airborne radioactivity levels are likely to result in an exposure to an individual exceeding 40 DAChours in one week (10CFR835.403(b)). No single failure of any barrier would result in airborne concentrations corresponding to an exposure of 40 DAC-hours in a week in occupied areas.

\section{Air Monitoring}

Implementation guidance provided in section IV of DOE G 441.8-1 specifies the air sampling shall be performed where an individual is likely to receive an exposure of 40 or more DAC-hours in a year and where respiratory protective devices for protection against airborne radionuclides have been prescribed (10CRT835.403(a)). Again, no single failure of any barrier would result in airborne concentrations corresponding to an exposure of 40 DAC-hours in a year.

In addition to the ${ }^{239} \mathrm{Pu}$ confined inside of many pieces of equipment such as hoods, gloveboxes, tanks, and miscellaneous vessels and bottles in the CAR and Mix Room, there is low level removable contamination on various surfaces in these rooms. Two barriers (i.e. the structure of the rooms, and the building ventilation) prevent migration of this removable contamination to occupied areas. This contamination would be the most likely source of exposure in occupied portions of the facility.

Radiological survey record \# W309924, dated 11/7/97 indicates a maximum removable contamination level of $859 \mathrm{dpm} / 100 \mathrm{~cm}^{2}$ in the Mix Room. This contamination was 
removed. The current maximum contamination level in the Mix Room is $367 \mathrm{dpm} / 100$ $\mathrm{cm}^{2}$. Using a standard resuspension factor of $10^{-6} / \mathrm{m}$ (NuReg 1400), there is a potential airborne concentration of ${ }^{239} \mathrm{Pu}$, for current facility operations, in the Mix Room of $1.7 \mathrm{x}$ $10^{-14} \mathrm{uCi} / \mathrm{ml}$ or $.008 \mathrm{DAC}$ for soluble ${ }^{239} \mathrm{Pu}$.

$$
\begin{gathered}
\frac{367 \mathrm{dpm}}{100 \mathrm{~cm}^{2}} \times \frac{m}{100 \mathrm{~cm}} \times \frac{10^{-6}}{\mathrm{~m}} \times \frac{\mu \mathrm{Ci}}{2.2 \times 10^{6} \mathrm{dpm}}=\frac{1.7 \times 10^{-14} \mu \mathrm{Ci}}{\mathrm{cm}^{3}} \\
\frac{1.7 \times 10^{-14} \mu \mathrm{Ci} / \mathrm{ml}}{2 \times 10^{-12} \mu \mathrm{Ci} / \mathrm{ml}}=0.008 \mathrm{DAC} C_{230_{\mathrm{Pu}}}
\end{gathered}
$$

As a worse case example:

- if the ventilation were to fail

- and if the integrity of the Mix Room were to simultaneously completely fail

- resulting in the same concentration in occupied areas of the building

- and one week were to elapse until the routine weekly survey detected the failure of the Mix Room containment

- the total potential exposure in occupied areas would be about .32 DAC-hours (40 work week hours $\times 0.008 \mathrm{DAC}$ ) or less than $1 \%$ of the level where air monitoring is required.

\section{Recommendations}

6.1. No routine air monitoring program is required in the $209 E$ Building during predeactivation activities. The status of the facility air monitoring requirements are reviewed annually, and documented in HNF-SD-WM-TA-179. This annual review is required by 10 CFR 835.

6.2. Airborne radioactivity area posting is not required for the CAR and Mix Room under the current conditions.
6.2.1. Air monitoring requirements will be reviewed and implemented on a job specific basis prior to any intrusive activities in the CAR or Mix Room.

6.3. Continue weekly contamination surveys of the CAR and Mix Room access doors to verify the integrity of these rooms. These surveys are required by HSRCM-1.

\subsubsection{If contamination levels in excess of HSRCM-1, Table 2-2 limits are} detected, the following steps are required:

- Decontaminate the area as required to reduce contamination to less than Table 2-2 limits.

- Locate and isolate the source of contamination.

- If decontamination efforts are unsuccessful, post and control the area as necessary. 
6.4. Continue quarterly contamination surveys of the CAR and Mix Room to verify the integrity of the primary containment (e.g., tanks, Lucite glove box covers) of the Pu inventory in these rooms. These surveys are required by HSRCM-1.

6.4.1. If contamination levels in the CAR or Mix Room exceed $880 \mathrm{dpm} / 100 \mathrm{~cm}^{2}$ (HNF-SD-WM-TA-179) are detected, the following steps are required:

- Decontaminate as required to reduce contamination to less than 880 $\mathrm{dpm} / 100 \mathrm{~cm}^{2}$.

- Locate and isolate the source of contamination.

- If decontamination efforts are unsuccessful, post the room as an airbome radioactivity area, and implement required controls.

\section{References}

- DOE G 441.8-1, Work Place Air Monitoring, U. S. Department of Energy Implementation Guide, January 1997

- HNF-SD-WM-TA-179, Rev. 1, Tank Farms Work Place Air Sampling

- HSRCM-1, Hanford Site Radiological Control Manual

- NUREG-1400, Air Sampling in the Workplace

- 10 CFR Part 835, Occupational Radiation Protection

- WHC 1996, Preliminary Hazards Analysis - 209-E Building Critical Mass Laboratory (CML), WHC-WM-TI-789 Rev 0, November 4, 1996. 
DISTRIBUTION SHEET

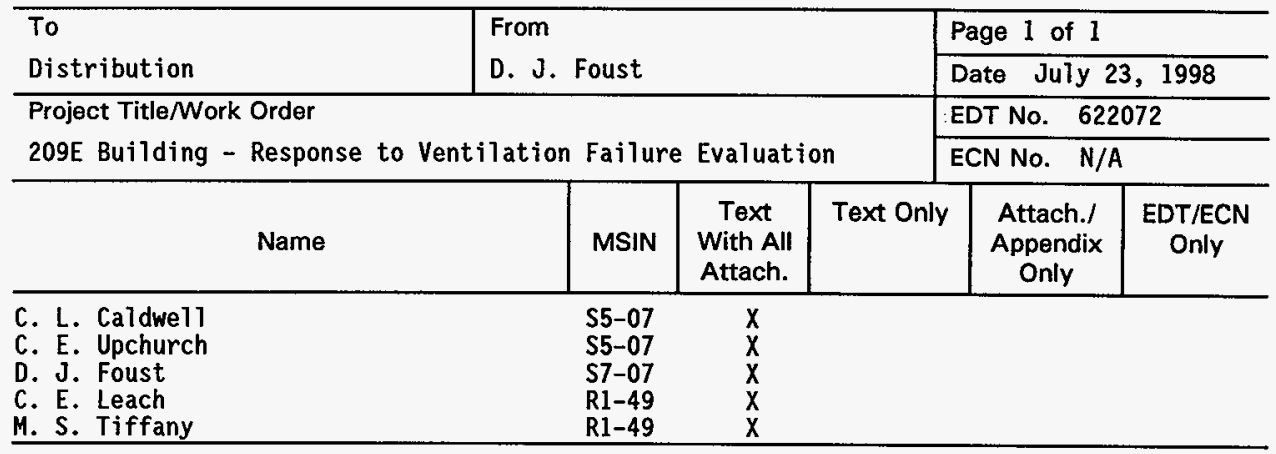

